\title{
Adib Domingos Jatene, 1929-2014
}

\author{
Domingo Braile, $\mathrm{MD},{ }^{\mathrm{a}}$ Enio Buffolo, $\mathrm{MD},{ }^{\mathrm{b}}$ and Tirone E. David, $\mathrm{MD}^{\mathrm{c}}$
}

Professor Adib Domingos Jatene died on November 14, 2014, in São Paulo, Brazil. He was born in a village called Xapuri, in the Brazilian state of Acre within the Amazon forest, on June 4, 1929. His parents were Lebanese immigrants and rubber merchants. His father died of yellow fever when Jatene was only 2 years old. Eight years later, the Jatene family moved to Uberlandia, in the Brazilian state of Minas Gerais. He was accepted at the Medical School of the University of São Paulo in 1948. He initially intended to specialize in public heath and return to his birthplace, where he had lost his father to a preventable disease; however, as a medical student he began to work as an assistant to a pioneer of cardiac surgery, Professor Euríclides de Jesus Zerbini. This experience changed his mind, and he decided to become a heart surgeon. Jatene joined Zerbini's group when he completed medical school, and together they created a research laboratory in the basement of the hospital, where they developed oxygenators, heat exchangers, and other important components of the cardiopulmonary bypass circuit. Jatene began to practice at the Institute of Cardiology of the State of São Paulo, now called the Institute of Cardiology Dante Pazzenese, in 1961. In addition to a busy clinical and academic practice, Jatene developed a company to manufacture artificial heart valves, equipment for cardiopulmonary bypass, pacemakers, ventricular assist devices, and other equipment that was designed, manufactured, commercialized, and distributed nationally and internationally.

When Zerbini retired in 1983, Jatene was elected professor and chief of the most revered cardiac institution in South America, the INCOR (Instituto do Coração), a teaching and research hospital with more than 600 beds funded by the state of São Paulo and entirely dedicated to the care of cardiac patients. He was also dean of the Medical School from 1990 through 1994. In addition to these academic posts, Jatene served as Secretary of Health for the State of São Paulo from 1979 through 1982 and as Minister of Health for Brazil in 1992 and again from 1996 through 1998.

\footnotetext{
From the Universidade Estadual de São Jose do Rio Preto, ${ }^{\text {a }}$ São Paulo, Brazil; the Universidade Federal de São Paulo, ${ }^{\mathrm{b}}$ São Paulo, Brazil; and the Department of Surgery, Toronto General Hospital, ${ }^{\mathrm{c}}$ Toronto, Ontario, Canada.

Disclosures: Authors have nothing to disclose with regard to commercial support.

Received for publication Dec 20, 2014; accepted for publication Dec 23, 2014; available ahead of print Jan 30, 2015.

Address for reprints: Tirone E. David, MD, Department of Surgery, University of Toronto, 200 Elizabeth St, 13EN219, Toronto, Ontario, Canada M5G 2C4 (E-mail: tirone.david@uhn.on.ca or Carolyn.Dunford@uhn.on.ca).

J Thorac Cardiovasc Surg 2015;149:959

$0022-5223 / \$ 36.00$

Copyright (C) 2015 by The American Association for Thoracic Surgery

http://dx.doi.org/10.1016/j.jtcvs.2014.12.065
}

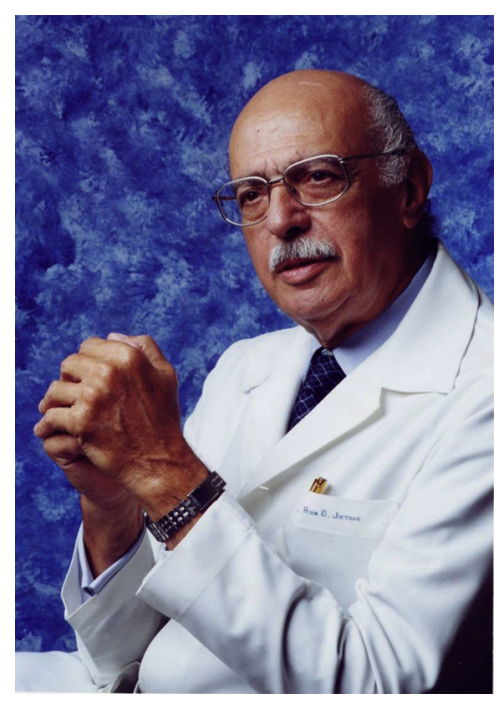

Adib Domingos Jatene, MD

Jatene retired as professor and chief of the INCOR in 1999 but continued to be active both clinically and academically. He personally operated on more than 20,000 patients, was the author or coauthor of approximately 800 publications and 4 books, and developed numerous operative procedures, among them the eponymous Jatene operation, first performed in 1975. He received numerous national and international prizes, awards, and honors. Jatene was elected as an honorary member of The American Association for Thoracic Surgery in 1985, and his Honored Guest Address was on surgical remodeling of the left ventricle for ventricular aneurysms.

Professor Jatene left an extraordinary legacy. He will be greatly missed by all of us, especially by Aurice, his wife of 60 years, and his children Fabio, Marcelo, Leda, Lara, their spouses, and his 10 grandchildren and 4 great grandchildren. 